\title{
Efektivitas Suhu dan Lama Pasteurisasi Pada Mutu Pasta Bawang merah (Alllium Cepa Var. Aggregatum) Kemasan Standing Pouch
}

\section{Effectiveness of Temperature and Old Temperatures in Quality Of Shallot Paste (Alllium cepa var. aggregatum) Standing Pouch Packaging}

\author{
Lorine Tantalu ${ }^{1}$, Rozana, dan Isrofatin ${ }^{1}$ \\ ${ }^{1}$ Program Studi Teknologi Industri Pertanian, Fakultas Pertanian \\ Universitas Tribhuwana Tunggadewi Malang \\ *E-mail : lorine.tantalu@unitri.ac.id
}

\begin{abstract}
Shallotpaste is an alternative product which can be applied as a spice, one of which is onion paste. This study aims to determine the temperature and duration of shallot paste pasteurization before being processed into onion paste in standing pouch package. Randomized block design (RBD) $2 \times 3$ used as design experiments with pasteurization temperature treatment as a $T$ factor, consisting of 2 levels, namely low-temperature long time (LTLT), called T1, that is red onion paste heated at $65^{\circ} \mathrm{C}$ for 30 minutes, and hightemperature short time (HTST), called T2, that is red onion paste heated at $75^{\circ} \mathrm{C}$ for 15 seconds. While the $S$ factor is the storage time consists of 5 levels, namely 4,8 and 12 days. Storage is carried out at room temperature $\left(27.5^{\circ} \mathrm{C}\right)$ with 3 replications. The quality observed was physical appearance, reinforced by the test parameters used including TPC and total acid. The results showed that there were changes in color and aroma that occurred after 12 days storage into brownish yellow due to enzymatic performance. $60^{\circ} \mathrm{C}$ pasteurization temperature in 30 minutes is recommended for processing onion paste seen from the TPC value below the maximum threshold of SNI with a maximum mean value of $9.103 \mathrm{CFU} / \mathrm{g}$.
\end{abstract}

Keywords: Shallot, Temperature and Duration of Pasteurization, Standing Pouch

Disubmit : 19 Juli 2018, Diterima: 09 September 2018, Disetujui : 28 September 2018

\section{PENDAHULUAN}

Salah satu produk unggulan yang memiliki permintaan pasar yang cukup tinggi pada komoditas hortikultura adalah bawang merah. Hal ini dikarenakan, hampir seluruh masakan Indonesia khususnya di Pulau Jawa menggunakan bawang merah untuk menjadi bumbu rempah inti. Laporan data statistik dari Kementerian Pertanian menunjukkan wilayah potensi pertanian bawang merah memiliki luas panen sampai dengan 1,68 juta ton di tahun 2017 (Kabung et al., 2017). Provinsi yang menjadi penyedia bawang merah diantaranya Sumatera Utara, Sumatera arat, Jawa Barat, Jawa Tengah, Daerah Istimewa Yogyakarta, Jawa Timur, Bali, Nusa Tenggara Barat dan Sulawei Selatan. Kondisi bahan segar yang melimpah, utamanya ketika panen raya berlangsung menggiatkan masyarakat untuk berlomba-lomba mendistribusikan Bawang merah baik dalam bentuk segar kupas maupun olahan pangan. Olahan Bawang merah yang banyak dijumpai diantaranya bawang goreng, stik bawang, tepung bawang hingga pasta bawang(Tulis and Kktm, 2008) 
Pasta bawang merah sebagai produk ringkas menjadi alternatif olahan bawang merah yang mengandung nutrisi yang cukup lengkap dibandingkan produk olahan bawang lainnya. Pasta bawang merah sendiri mengandung lemak, protein, karbohidrat, dan vitamin C (Saputra, Pontoh and Momuat, 2015). Tingkat keawetan dan kepraktisan serta harga yang terjangkau menjadikan produk ini sangat kompetitif dengan produk olahan bawang merah lainnya. Permintaan bumbu dasar dapur yang cukup besar, menjadikan pengolahan produk ini sebagai lapangan kerja baru yang cukup menjanjikan. Pangsa pasar pasta bawang merah ini pun cukup luas, diantaranya adalah para ibu rumah tangga, para juru masak, dan para pedagang masakan termasuk rumah makan dan hotel (Sari, 2008).

Hal yang perlu diperhatikan dalam pengolahan pasta bawang yaitu kondisi pra-produksi. Sifat bulky dan tidak tahan lama yang dimiliki oleh bawang merah menjadi tantangan tersendiri dalam meningkatkan mutu suatu produk. Pengolahan dengan suhu tertentu saat pra-produksi merupakan hal penting yang perlu dilakukan untuk menonaktifkan enzim alami yang terkandung dalam bawang merah. Penelitian ini bertujuan untuk mendapatkan suhu dama lama pasteurisasi yang tepat dalam penanganan Bawang merah untuk menjadi pasta. Kemasan standing pouch dipilih karena lebih praktis, ekonomis, dan mudah didapatkan. Pemilihan kemasan yang baik harus disesuaikan dengan karakteristik bahan yang dikemas, suhu dan lama simpan bahan pangan (Permatasari, dkk 2017).

\section{METODE PENELITIAN}

Peneltiian ini dilakukan di laboratorium Mikrobiologi Industri Fakultas Pertanian Universitas Tribhuwana Tunggadewi Malang yang dilakukan mulai bulan Mei hingga Agustus 2018. Bahan utama yang digunakan dalam penelitian ini adalah bawang merah yang diperoleh dari desa Ngantang Kabupaten Malang. Bahan tambahan dalam proses pembuatan pasta bawang merah adalah asam sitrat teknis. Bahan lainnya adalah kemasan standing pouch jenis flat bottom pouch berbahan metalized foil sebanyak 18 pcs.

Alat-alat yang digunakan dalam penelitian meliputi peralatan sederhana untuk replika pasteurisasi seperti panci pemanas, kompor, thermometer dan beberapa sendok plastik. Alat-alat untuk pembuatan pasta bawang merah meliputi pisau, talenan, baskom platik, blender dan sendok plastik. Pengujian parameter Kadar Air (Kumesan, 2017) dengan metode pengeringan dilakukan di Laboratorium Rekayasa Proses Fakultas Pertanian Universitas Tribhuwana Tunggadewi Malang. Untuk pengujian Total Plating Count (TPC) metode spread plate (Cahyono, et al. 2013)dilakukan di Laboratorium Mikrobiologi Industri Proses Fakultas Pertanian Universitas Tribhuwana Tunggadewi Malang. Pengujian Total Asam metode AOAC 935.57 (Yulianawati and Isworo, 2012) dilakukan di Laboratorium pangan THP, Universitas Brawijaya Malang.

Persiapan dan Pengolahan Pasta Bawang Merah. Penelitian ini dilakukan dalam beberapa kegiatan yaitu proses persiapan bahan dan pengolahan menjadi pasta bawang. Proses persiapan bawang merah mencakup sortasi bawang merah segar, pengupasan, pencucian dengan air matang hangat, blansir selama 10 menit dengan air bersuhu $70^{\circ} \mathrm{C}$, dan penirisan. Pengolahan menjadi pasta bawang dimulai dengan penghancuran bawang merah dengan blender selama 10 menit. Dilanjutkan dengan pemberian asam sitrat 5\% dan dihomogenisasi. Selanjutnya dilakukan pasteurisasi dan pengemasan dalam standing pouch.

Penentuan Masa Simpan Pasta Bawang Merah dalam Kemasan Standing Pouch. Penentuan masa simpan untuk produk Pasta Bawang Merah pada kemasan standing pouch dalam penelitian ini, menggunakan konvensional sederhana yang dikenal dengan metode ESS (Extended Storage Studies) (Permatasari, dkk, 2017). Metode yang dimaksud yaitu dengan menyimpan Pasta Bawang Merah sampai layak untuk digunakan. Kelayakan yang dimaksud dintinjau dari segi fisik dan biologi. Metode ESS umum digunakan untuk produk dengan masa simpan tidak lebih dari 3 bulan masa penyimpanan 
Rancangan Percobaan. Rancangan penelitian menggunakan rancangan acak kelompok (RAK) pola faktorial $2 \times 3$ dengan perlakuan suhu pasteurisasi sebagai faktor $\mathrm{T}$, terdiri dari 2 taraf, yaitu low temperature long time (LTLT), disebut $\mathrm{T}_{1}$, yaitu pasta bawang merah dipanaskan pada suhu $65^{\circ} \mathrm{C}$ selama 30 menit, dan high temperature short time (HTST), disebut $\mathrm{T}_{2}$, yaitu pasta bawang merah dipanaskan pada suhu $75^{\circ} \mathrm{C}$ selama 15 detik. Sedangkan faktor S, adalah lama penyimpanan terdiri dari 5 taraf yaitu 4, 8 dan 12 hari. Penyimpanan dilakukan pada suhu kamar $\left(27.5^{\circ} \mathrm{C}\right)$ dengan ulangan sebanyak 3 kali

\section{HASIL DAN PEMBAHASAN}

Persiapan Bawang Merah. Kegiatan awal dalam penelitian ini dimulai dengan pemilihan (sortir) bawang merah yang dapat digunakan, dilanjutkan dengan proses pengupasan. Pengupasan bertujuan untuk menghindari masuknya sumber kontaminan mikroba melalui kulit. Selanjutnya dilakukan pencucian bawang merah dengan menggunakan air matang hangat yang mengalir untuk menghilangkan kotoran untuk kemudian ditiriskan. Sebelum dilakukan penghancuran bawang merah menjadi pasta, dilakukan proses blansir terlebih dahulu. Blansir atau blanching menjadi bagian dari proses penting yang berfungsi untuk menghambat laju aktifitas proses enzimatis (Afrianto, et al, 2015)

Pengolahan Pasta Bawang Merah. Bawang merah yang telah diblansir dihancurkan dengan blender selama 10 menit. Waktu ini cukup panjang mengingat produk akhir yang diinginkan adalah dalam bentuk bubur. Pada penelitian ini, pasta bawang merah tidak dilakukan penambahan bahan tambahan makanan seperti shorthening maupun emulsifier. Hal ini dimaksudkan untuk menjaga kemurnian dari pasta bawang dan menghindari kebergantungan produksi dengan bahan-bahan tersebut. Bahan yang ditambahkan adalah asam sitrat sebanyak 5\%. Penambahan asam sitrat, dapat memberikan suasana asam dan penyegar serta mampu menjadi bahan pengawet pada produk pangan(Saputra, et al. 2015). Pertumbuhan bakteri juga dipengaruhi oleh tinggi rendahnya $\mathrm{pH}$ karena berkaitan langsung dengan aktifitas enzim (Cahyono, et al., 2013). Beberapa dari bakteri dapat hidup dengan sistem kerja enzim, apabila kondisi pH tidak optimum akan mengganggu pertumbuhan dari bakteri. Kisaran $\mathrm{pH}$ optimum untuk pertumbuhan bakteri adalah 4-9 (Erni, 2009). Proses setelah penirisan dilanjutkan dengan menghancurkan bawang merah sampai menjadi bubur baru dipasteurisasi. Pasteurisasi dimaksudkan untuk membunuh bakteri patogen dengan pemanasan dibawah suhu $100^{\circ} \mathrm{C}$ dan menginaktifkan enzim pada bahan pangan (Rahmi, et al.2018). Tahap akhir yaitu pengemasan pasta bawang menggunakan kemasan standing pouch.

Penentuan Lama Simpan Pasta Bawang Merah dalam Kemasan Standing Pouch. Hasil penelitian ini menunjukkan bahwa pasta bawang merah tanpa penambahan shortening dan emulsififer menunjukkan adanya perubahan warna yang cukup signifikan apabila disimpan dalam suhu ruang $\left(27,5^{\circ} \mathrm{C}\right)$. Hasil pengamatan masa simpan menunjukkan bahwa, penerapan kedua suhu dan lama pasteurisasi yang berbeda untuk produk pasta bawang merah menunjukkan perubahan warna. Gambar 1 menunjukkan, bahwa pada hari ke - 0 menunjukkan warna produk yang merah bata, dan setelah 12 hari akan berubah warna menjadi kuning kecoklatan dipermukaan dan disertai bau yang tidak sedap.

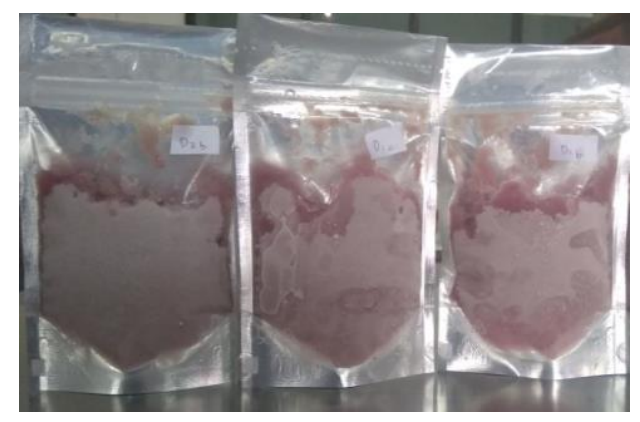

a

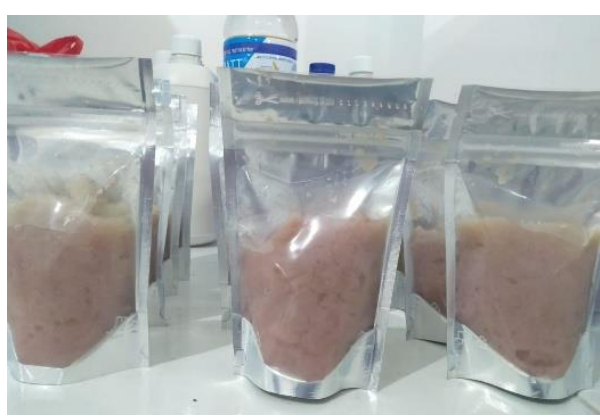

b 
Gambar 1. Perubahan kondisi fisik pasta bawang merah yang awalnya merah (a) menjadi kuning kecoklatan dipermukaan (b).

Perubahan warna kuning kecoklatan pada produk pasta bawang merah menandakan adanya proses enzimatis yang terus berjalan. Hal ini dimungkinkan proses blansir yang diterapkan membutuhkan waktu yang lebih lama. Penelitian dari Fajar (2013) menunjukkan, proses blansir selama lebih dari 10 menit (15-20) pada suhu $70^{\circ} \mathrm{C}$ akan menambah kadar lemak. Hal ini akan berakibat pada mudahnya produk mengalami oksidasi.

Total Asam. Penerapan suhu pasteurisasi $75^{\circ} \mathrm{C}$ selama 15 detik menunjukkan bahwa produk pasta bawang memiliki pH yang cukup rendah jika dibandingkan dengan penerapan suhu $65^{\circ} \mathrm{C}$ selama 30 menit. Tabel 1 menunjukkan perbedaan cukup nyata tentang penerapan suhu $65^{\circ} \mathrm{C}$ selama 30 menit dan $75^{\circ} \mathrm{C}$ selama 15 detik dalam masa penyimpanan 4, 8, dan 12 hari menunjukkan pengaruh yang berbeda sangat nyata. Ketika dihitung dengan analisa rancangan percobaan didapatkan bahwa nilai $\mathrm{F}$ hitung $>\mathrm{F}$ Tabel pada nilai kelompok, perlakuan kombinasi, dan lama penyimpanan maka disimpulkan bahwa nilai kelompok, perlakuan kombinasi, dan lama penyimpanan berbeda sangat nyata.

Tabel 1. Total asam produk Pasta Bawang Merah

\begin{tabular}{ccccccc}
\hline Suhu & $\begin{array}{c}\text { Lama } \\
\text { Penyimpanan }\end{array}$ & $\mathrm{U} 1$ & $\mathrm{U} 2$ & $\mathrm{U} 3$ & Total & Rerata \\
\hline $65^{\circ} \mathrm{C}$ & 0 & $1,28 \mathrm{a}$ & $1,50 \mathrm{a}$ & $1,58 \mathrm{a}$ & 4,36 & 1,46 \\
& 4 & $1,88 \mathrm{~b}$ & $1,87 \mathrm{~b}$ & $1,90 \mathrm{~b}$ & 5,65 & 1,89 \\
& 8 & $1,91 \mathrm{c}$ & $1,99 \mathrm{c}$ & $2,42 \mathrm{c}$ & 6,32 & 2,10 \\
$75^{\circ} \mathrm{C}$ & 12 & $2,47 \mathrm{~d}$ & $3,02 \mathrm{~d}$ & $3,48 \mathrm{~d}$ & 8,97 & 2,99 \\
& 0 & $1,21 \mathrm{a}$ & $1,37 \mathrm{a}$ & $1,41 \mathrm{a}$ & 3,99 & 1,33 \\
& 4 & $1,96 \mathrm{~b}$ & $2,01 \mathrm{~b}$ & $1,78 \mathrm{~b}$ & 5,75 & 1,91 \\
& 8 & $2,06 \mathrm{c}$ & $2,17 \mathrm{c}$ & $2,01 \mathrm{c}$ & 6,24 & 2,08 \\
\hline
\end{tabular}

Kondisi pH yang kurang dari 4 merupakan kondisi dimana pertumbuhan bakteri tidak dapat tumbuh secara optimal. Hal ini menunjukkan bahwa penerapan pasteurisasi dan penambahan asam sitrat mempengaruhi total asam yang terdapat pada produk pasta bawang merah. Asam yang terdapat pada produk pasta bawang merupakan asam organik yang berperan penting dalam karakteristik produk, baik aroma maupun rasa (Sari, 2008)

Total Plate Counting (TPC). Hasil pengujian TPC pada produk pasta bawang merah dengan menerapkan suhu dan lama pasteurisasi yang berbeda tercantum pada Tabel 2. Penerapan suhu dan lama pasteurisasi tersebut tidak berbeda nyata. Hal ini diperkuat dengan perhitungan rancangan acak kelompok faktorial dengan hasil nilai F-hitung lebih besar dibandingkan dengan $\mathrm{F}$ tabel pada nilai kelompok, perlakuan dan interaksi suhu dan lama penyimpanan, maka disimpulkan bahwa kelompok, perlakuan kombinasi, interaksi suhu- lama penyimpanan tidak berbeda nyata.

Tabel 2. Hasil perhitungan TPC pada produk pasta bawang merah

\begin{tabular}{ccccccc}
\hline Suhu & $\begin{array}{c}\text { Lama } \\
\text { penyimpanan }\end{array}$ & $U 1$ & $U 2$ & $\mathrm{U} 3$ & Total & Rerata \\
\hline $65^{\circ} \mathrm{C}$ & 0 & $1.10^{3} \mathrm{a}$ & $4.10^{3} \mathrm{a}$ & $3.10^{3} \mathrm{a}$ & $8,10^{3}$ & $2,66.10^{3}$ \\
& 4 & $3.10^{3} \mathrm{~b}$ & $1,3.10^{3} \mathrm{~b}$ & $1,1.10^{3} \mathrm{~b}$ & $5,31.10^{3}$ & $2,52.10^{3}$ \\
& 8 & $5.10^{3} \mathrm{c}$ & $3.10^{3} \mathrm{c}$ & $5,3.10^{3} \mathrm{c}$ & $1,3.10^{4}$ & $9,00.10^{3}$ \\
$75^{\circ} \mathrm{C}$ & 12 & $8.2 .10^{3} \mathrm{~d}$ & $4.10^{3} \mathrm{~d}$ & $3.10^{3} \mathrm{~d}$ & $8,10^{3}$ & $9,66.10^{3}$ \\
& 0 & $4.10^{3} \mathrm{a}$ & $4.10^{3} \mathrm{a}$ & $3.10^{3} \mathrm{a}$ & $1,1.10^{4}$ & $3,66.10^{3}$ \\
& 4 & $5.10^{3} \mathrm{~b}$ & $4.10^{3} \mathrm{~b}$ & $2.10^{3} \mathrm{~b}$ & $1,1.10^{4}$ & $3,66.10^{3}$
\end{tabular}


Kusuma dkk : Efisiensi Pupuk Urea Dan Lahan Dalam Meningkatkan Hasil Jagung “Double Row”...

\begin{tabular}{cccccc}
8 & $3.10^{3} \mathrm{c}$ & $4.10^{3} \mathrm{c}$ & $1.10^{3} \mathrm{c}$ & $8.10^{3}$ & $2,66.10^{3}$ \\
12 & $1.410^{4} \mathrm{~d}$ & $2.10^{3} \mathrm{~d}$ & $9.10^{3} \mathrm{~d}$ & $2,1.10^{4}$ & $7,00.10^{3}$ \\
\hline
\end{tabular}

Keterangan : Satuan TPC $=\mathrm{CFU} / \mathrm{g}$

Hasil perhitungan TPC tersebut menunjukkan bahwa proses pasteurisasi efektif dalam menghambat pertumbuhan mikroba dengan menerapkan suhu $60^{\circ} \mathrm{C}$ selama 30 menit. Berdasar pada SNI 7388:2009 untuk batas maksimum cemaran mikroba dalam pangan produk pasta menunjukkan bahwa batas maksimum TPC adalah tidak lebih dari $1.10^{4} \mathrm{cfu} / \mathrm{g}\left(30^{\circ} \mathrm{C}, 72 \mathrm{jam}\right)$. Hasil penelitian menunjukkan bahwa nilai rerata TPC pada pasta bawang baik suhu pasteurisasi $65 \mathrm{oC}$ dan $75 \mathrm{oC}$ masih dibawah ambang SNI. Pengujian TPC dapat menunjukkan tingkat kebersihan sanitasi saat proses pembuatan produk, keberadaan mikroba yang terdapat dilingkungan serta dapat menjadi indikator pengawasan produk untuk dapat diterima konsumen. Jumlah angka TPC menunjukkan banyaknya mikroba aerobik dan mesofilik yang tumbuh pada suhu ruang antara 20-45 ${ }^{\circ} \mathrm{C}$ menggunakan media yang tidak selektif. Dapat dikatakan bahwa bakteri yang dihitung mencakup bakteri berbahaya (patogen) maupun tidak pada proses produksi dan produk yang dihasilkan (Rahmi, et al. 2018).

\section{KESIMPULAN}

Penelitian ini dapat disimpulkan bahwa penerapan suhu dan lama pasteurisasi $65^{\circ} \mathrm{C}$ selama 30 menit dan $75^{\circ} \mathrm{C}$ selama 15 detik tidak berpengaruh nyata pada perubahan fisik warna dan aroma dari pasta bawang merah. Hal ini ditunjukkan dengan perubahan warna produk pasta pada kedua penerapan suhu dan lama pasteurisasi yang berbeda menjadi kuning kecoklatan setelah 12 hari penyimpanan. Penggunaan suhu $75^{\circ} \mathrm{C}$ selama 15 detik pasteurisasi cenderung meningkatkan total asam pada penyimpanan 12 hari, namun memiliki nilai TPC yang cukup tinggi. Berbeda halnya dengan penerapan suhu $60^{\circ} \mathrm{C}$ selama 30 menit yang memiliki nilai TPC dibawah ambang maksimal SNI. Saran kedepan yaitu perlu dilakukan penelitian lebih lanjut mengenai upaya penghambatan kinerja enzim dan tumbuhnya bakteri untuk penyimpanan produk pasta bawang pada suhu kamar.

\section{UCAPAN TERIMA KASIH}

Ucapan terima kasih diberikan kepada Universitas Tribhuana Tunggadewi Malang yang telah memberikan dana Hibah Penelitian dengan surat perjanjian penugasan dalam rangka pelaksanaan program penugasan hibah penelitian mandiri sumber dana Universitas Tribhuwana Tunggadewi Tahun Anggaran 2018, No. Kontrak : 127 / TB-PPM / TU - 220 / IV / 2018.

\section{DAFTAR PUSTAKA}

Afrianto, E. et al. (2015) 'Pengaruh Suhu dan Lama Blansing Terhadap Penurunan Kesegaran Filet Tagih Selama Penyimpanan Pada Suhu Rendah', Jurnal Akuatika, 5(1). Available at: http://jurnal.unpad.ac.id/akuatika/article/view/3704.

Ayu Permatasari, N., Yuliasih, I. and Suryani, A. (2017) 'Proses Pembuatan Pasta Bawang Merah (Allium cepa var. aggregatum) dan Penentuan Umur Simpannya Dalam Kemasan Gelas', Jurnal Teknologi Industri Pertanian, 27(2), pp. 200-208. doi: 10.24961/j.tek.ind.pert.2017.27.2.200.

Cahyono, Dwi , Masdiana dan Manik, Eirry, S. (2013) 'Kajian Kualitas Mikrobiologis Total Plate Count ( TPC ), Enterobacteriae dan Staphylococcus aureus ) Susu Sapi Segar di Kecamatan Krucil Kabupaten Probolinggo', Jurnal Ilmu dan Teknologi Hasil Ternak, 8(1), pp. 1-8. Available at: http://jitek.ub.ac.id/index.php/jitek/article/download/170/161.

Erni, G. (2009) 'Pengendalian Cemaran Mikroba Pada Bahan Pangan Asal Ternak (Daging Dan Susu) Mulai Dari Peternakan Sampal Dihidangkan', 28(80). 
Evan Ch. Kumesan, E. V. P. dan H. J. L. (2017) 'Analisa Total Bakteri , Kadar Air Dan Ph Pada Rumput Laut ( Kappaphycus alvarezii ) Dengan Dua Metode Pengeringan', Jurnal Media Teknologi Hasil Perikanan, 5(1), pp. 124-129.

Kabung, T. et al. (2017) ‘1), 2), 1)’, 3(2), pp. 113-120.

Rahmi, A. D., Dien, H. A. and Kaparang, J. T. (2018) 'Mutu Mikrobiologi Dan Kimia Dari Produk Pasta ( Intermediet Product ) Penyedap Rasa Alami’, 6(2), pp. 238-243.

Saputra, K. A., Pontoh, J. S. and Momuat, L. I. (2015) 'Analisis Kandungan Asam Organik pada Beberapa Sampel Gula Aren', 4(1), pp. 69-74.

Sari, N. (2008) 'Kelayakan Usaha Agroindustri Bawang Goreng Palu Di Kabupaten Donggala, 15(September), pp. 216-222.

Tulis, K. and Kktm, M. (2008) 'Pemanfaatan Bawang Merah ( Allium cepa L .) sebagai Agen KoKemoterapi', pp. 1-36.

Yulianawati, T. A. and Isworo, J. T. (2012) 'Perubahan Kandungan Beta Karoten, Total Asam , dan Sifat Sensorik Yoghurt Labu Kuning Berdasarkan Lama Simpan dan Pencahayaan’, Journal Pangan dan Gizi, 03(06), pp. 37-48. 